\section{PENGARUH FINANCIAL DISTRESS, PERTUMBUHAN PERUSAHAAN, RENTABILITAS, UKURAN KAP, DAN UKURAN PERUSAHAAN TERHADAP PERGANTIAN AUDITOR}

\author{
Sri Maryani, Novita Weningtyas Respati, Lili Safrida \\ Fakultas Ekonomi dan Bisnis Universitas Lambung Mangkurat \\ Email:novifeunlam@yahoo.co.id
}

\begin{abstract}
ABSTRAK
Penelitian ini bertujuan untuk menguji dan menganalisis pengaruh financial distress, pertumbuhan perusahaan, rentabilitas, ukuran KAP dan ukuran perusahaan terhadap pergantian auditor. Penelitian ini merupakan penelitian kuantitatif. Jenis data yang digunakan ialah data kuantitatif dan sumber data yang digunakan adalah sumber data sekunder. Penelitian ini dilakukan pada perusahaan manufaktur yang terdaftar di Bursa Efek Indonesia tahun 2008-2015 dengan jumlah pengamatan sebanyak 52 sampel penelitian yang diperoleh dengan metode purposive sampling. Pengumpulan data dalam penelitian ini menggunakan metode dokumentasi. Teknik analisis data dengan menggunakan analisis regresi logistik. Hasil penelitian ini menunjukkan bahwa variabel financial distress, pertumbuhan perusahaan dan ukuran perusahaan tidak berpengaruh terhadap pergantian auditor.Sedangkan variabel rentabilitas ukuran KAP berpengaruh terhadap pergantian auditor.
\end{abstract}

Kata Kunci: Pergantian Auditor, Financial Distress, Pertumbuhan Perusahaan, Rentabilitas, Ukuran Kantor Akuntan Publik, dan Ukuran Perusahaan

\section{PENDAHULUAN}

Laporan keuangan yang dibuat oleh manajemen berpotensi dipengaruhi oleh kepentingan-kepentingan pribadi manajemen. Oleh karena itu, dibutuhkan jasa auditor independen untuk meningkatkan keandalan laporan keuangan dan meyakinkan para pemilik perusahaan bahwa laporan keuangan telah disajikan secara wajar. Pemeriksaan yang dilakukan oleh auditor harus objektif dan independen terhadap informasi yang disajikan dalam laporan keuangan sehingga dapat diperoleh informasi keuangan yang handal sebagai bahan pertimbangan dalam pengambilan keputusan (Aprilia 2013).

Independensi merupakan kunci utama seorang auditor untuk menilai kewajaran laporan keuangan yang diperiksanya. Independensi seorang auditor akan terancam apabila auditor memiliki hubungan kerjasama yang lama dengan kliennya. Hubungan antara klien dan auditor dengan masa perikatan (tenure) audit yang lama membuat klien merasa nyaman dengan auditornya selama ini, dan auditor akan terikat emosional dan mengancam independensinya (Arsih dan Anisykurlillah 2015).

Salah satu usaha untuk mencegah auditor terlalu dekat berinteraksi dengan klien yang dapat mengganggu independensi auditor adalah dengan membatasi masa perikatan audit. Pembatasan masa perikatanaudit bisa dilakukan dengan cara mengeluarkan peraturan-peraturan yang mengatur pergantian auditor dan Kantor Akuntan Publik (KAP) secara wajib (mandatory). Pembatasan masa perikatan audit di Indonesia diatur oleh pemerintah dengan dikeluarkannya Keputusan 
Pengaruh

Financial

Distress...

874
Menteri Keuangan Republik Indonesia Nomor 359/KMK.06/2003 pasal 2 tentang "Jasa Akuntan Publik" (perubahan atas Keputusan Menteri Keuangan Republik Indonesia Nomor 423/KMK.06/2002). Peraturan ini menyatakan bahwa pemberian jasa audit umum atas laporan keuangan dari suatu entitas dapat dilakukan oleh Kantor Akuntan Publik (KAP) paling lama untuk 5 (lima) tahun buku berturutturut dan oleh seorang akuntan publik paling lama untuk 3 (tiga) tahun buku berturut-turut.

Peraturan tersebut kemudian disempurnakan dengan dikeluarkannya Peraturan Menteri Keuangan Republik Indonesia Nomor 17/PMK.01/2008 tentang "Jasa Akuntan Publik". Peraturan ini memiliki dua perubahan. Perubahan pertama adalah pemberian jasa audit umum menjadi 6 (enam) tahun berturut-turut oleh KAP dan 3 (tiga) tahun berturut-turut oleh akuntan publik kepada satu klien yang sama (pasal 3 ayat 1). Perubahan kedua adalah KAP dan akuntan publik boleh menerima kembali penugasan setelah 1 (satu) tahun buku tidak memberikan jasa audit kepada klien yang di atas (pasal 3 ayat 2 dan 3 ).

Adanya peraturan yang membatasi masa perikatan audit tidak menjamin bahwa perusahaan tidak akan melakukan pergantian auditor sebelum berakhirnya batas waktu yang ditentukan dalam peraturan. Pergantian auditor sebelum berakhirnya batas waktu yang ditentukan dalam peraturan disebut pergantian auditor secara sukarela (voluntary). Pergantian auditor secara voluntary dapat dipicu oleh klien maupun oleh KAP. Pergantian auditor yang dipicu oleh klien biasanya disebabkan karena klien ingin mencari auditor dengan kualitas yang lebih baik, opinion shopping, dan meminumkan biaya audit (Elder et all. 2011: 81). Sementara itu, pergantian auditor yang dipicu oleh auditor biasanya disebabkan karena fee audit dan kualitas audit (Mardiyah, 2002 dalam Wijayani dan Januart 2011).

Penelitian ini mencoba untuk meneliti faktor-faktor yang mempengaruhi pergantian auditor pada suatu perusahaan. Faktor-faktor yang diduga berpengaruh terhadap pergantian auditor adalah financial distress, pertumbuhan perusahaan, rentabilitas, ukuran KAP, dan ukuran perusahaan.Penelitian yang dilakukan oleh Pratini dan Astika (2013) dan Wijaya dan Rasmini (2015) menemukan adanya hubunga positif signifikan antara financial distres dengan pergantian auditor. Sedangkan penelitian yang dilakukan oleh Wijaya (2011), Putra (2014), dan Pradhana dan Suputra (2015) tidak menemukan pengaruh yang signifikan antara financial distress dengan pergantian auditor. Penelitian yang dilakukan oleh Putra (2014) menjelaskan bahwa pertumbuhan perusahaan tidak memiliki pengaruh terhadap pergantian auditor yang dilakukan oleh perusahaan. Sementara itu, penelitian yang dilakukan oleh Wijaya (2011) yang menyatakan bahwa pertumbuhan perusahaan berpengaruh signifikan terhadap pergantian auditor.

Penelitian yang dilakukan oleh Putra (2014) dan Arsih dan Anisykurlillah (2015) yang menunjukkan bahwa rentabilitas sama sekali tidak mempengaruhi pergantian auditor yang dilakukan oleh perusahaan. Penelitian yang dilakukan oleh Wijaya (2011) menemukan fakta bahwa ukuran KAP mempengaruhi pergantian auditor dengan signifikan. Namun, penelitian ini berbeda dengan penelitian yang dilakukan oleh Pratini dan Astika (2013) dan Wijaya dan Rasmini (2015) yang mengatakan bahwa ukuran KAP tidak berpengaruh terhadap pergantian auditor yang dilakukan perusahaan.

Hasil penelitian yang dilakukan oleh Astuti dan Ramantha (2014) menunjukkan fakta bahwa ukuran perusahaan mempengaruhi pergantian auditor. Sementara penelitian yang dilakukan oleh Wijaya dan Rasmini (2015) menemukan fakta yang berbeda, ukuran perusahaan tidak berpengaruh terhadap pergantian auditor yang dilakukan oleh perusahaan.Perbedaan dari hasil penelitian di atas memberikan motivasi bagi peneliti untuk meneliti kembali mengenai "Pengaruh Financial Distress, Pertumbuhan Perusahaan, Rentabilitas, Ukuran Kantor Akuntan Publik, dan Ukuran Perusahaan Terhadap Pergantian Auditor (Studi Empiris pada Perusahaan Manufaktur yang Terdaftar di Bursa Efek Indonesia Tahun 2008-2015). 


\section{Teori Agensi}

Hubungan agensi muncul ketika pemilik (prinsipal) memberikan mandat pada manajer (agen) untuk mengelola perusahaan yang dimilikinya. Manajer dalam mengelola perusahaan cenderung mementingkan kepentingan pribadi daripada kepentingan untuk meningkatkan nilai perusahaan. Manajer bertindak untuk mencapai kepentingan mereka sendiri, padahal sebagian manajer seharusnya memihak kepada pemilik karena mereka adalah pihak yang memberi kuasa untuk mengelola perusahaan (Ikhsan, Lesmana, dan Hayat 2015: 81). Masalah yang kemudian muncul dalam hubungan keagenan adalah asimetri informasi. Untuk menyelesaikan permasalahan ini, diperlukan campur tangan pihak ketiga. Pihak ketiga yang dimaksud adalah auditor sebagai pihak independen untuk menyelesaiakn permasalahan tersebut. Auditor dapat memberikan keyakinan dan menilai apakah laporan keuangan yang dibuat oleh manajemen perusahaan telah disajikan secara wajar sesuai dengan keadaan yang sesungguhnya. Oleh karena itu, perusahaan memiliki kriteria tersendiri dalam menentukan auditor yang akan melakukan audit atas laporan keuangannya. Apabila perusahaan memandang auditor sudah tidak cocok dan sesuai degan kebutuhan dan keinginan perusahaan, maka perusahaan akan mengganti auditor tersebut dengan auditor baru yang dianggap cocok dan sesuai dengan kebutuhan perusahaan.

\section{Pergantian Auditor}

Pergantian auditor merupakan perilaku yang dilakukan oleh perusahaan untuk berpindah auditor. Pergantian auditor bisa disebabkan oleh kewajiban rotasi audit yang diatur oleh pemerintah (mandatory) atau pergantian secara sukarela (voluntary). Pergantian auditor secara wajib dan secara sukarela bisa dibedakan atas dasar pihak mana yang menjadi fokus perhatian dari isu tersebut..Menurut Mardiyah (2002) dalam Wijayani\& Januarti (2011) menyatakan bahwa ada dua faktor yang mempengaruhi perusahaan melakukan pergantian auditor. pertama, faktor klien (Client-related Factors), yaitu: financial distress, manajemen yang gagal, perubahan ownership, Initial Public Offering (IPO). Kedua, faktor auditor (Auditor-related Factors), yaitu: fee audit dan kualitas audit.

\section{Pengaruh Financial Distress Terhadap Pergantian Auditor}

Financial distress merupakan suatu kondisi dimana perusahaan mengalami kondisi yang tidak sehat ataupun kesulitan dalam keuangannya sehingga dikhawatirkan akan mengalami kebangkrutan (Wijaya 2011). Financial distress dimulai ketika perusahaan tidak dapat memenuhi jadwal pembayaran atau ketika proyeksi arus kas mengindikasikan bahwa perusahaan tersebut akan segera tidak dapat memenuhi kewajibannya (Brigham dan Daves 2003).

Ketidakpastian dalam bisnis pada perusahaan-perusahaan yang mengalami financial distress menimbulkan kondisi yang mendorong perusahaan mengganti auditornya. Hal ini dikarenakan menurunnya kemampuan keuangan perusahaan sehingga perusahaan sudah tidak lagi memiliki kemampuan untuk membayar fee audit yang tinggi sehingga perusahaan akan mengganti dengan auditor yang memiliki fee audit lebih rendah (Pratini dan Astika 2013).

$\mathrm{H}_{1}$ : Financial distress berpengaruh terhadap pergantian auditor

\section{Pengaruh Pertumbuhan Perusahaan Terhadap Pergantian Auditor}

Pertumbuhan perusahaan merupakan hal yang penting bagi perusahaan. Tingkat pertumbuhan perusahaan menjadi salah satu hal yang perlu dipertimbangkan bagi investor untuk membuat keputusan terhadap investasinya. Pertum- 
Pengaruh

Financial

Distress...

876 buhan perusahaan menunjukkan bahwa bisnis yang dikelola perusahaan ridak mengalami stagnancy (Wijaya, 2011). Nabila (2011) dalam Pradipta (2014) menyatakan bahwa tingkat pertumbuhan perusahaan merupakan seberapa baik perusahaan mempertahankan posisi ekonominya. Baik dalam industrinya maupun dalam kegiatan ekonomi secara keseluruhan.

$\mathrm{H}_{2}$ : Pertumbuhan Perusahaan berpengaruh terhadap Pergantian Auditor

\section{Pengaruh Rentabilitas Terhadap Pergantian Auditor}

Menurut Munawir (2014: 33), rentabilitas atau profitability adalah kemampuan perusahaan untuk menghasilkan laba selama periode tertentu. Sementara itu, Kasmir (2011: 197) mendefinisikan rentabilitas sebagai rasio untuk menilai kemampuan perusahaan dalam mencari keuntungan. Rentabilitas suatu perusahaan diukur dengan kesuksesan perusahaan dan kemampuan menggunakan aktivanya secara produktif, dengan demikian rentabilitas suatu perusahaan dapat diperoleh dalam suatu periode dengan jumlah aktiva atau jumlah modal perusahaan tersebut. Wijaya (2011) mengatakan bahwaperusahaan yang memperoleh peningkatan profitabilitas maka perusahaan mengalami pertumbuhan pada perusahaannya, dengan demikian perusahaan yang sedang mengalami pertumbuhan akan cenderung untuk melakukan auditor switching. Hal ini dikarenakan perusahaan memerlukan auditor yang kredibilitas dan tingkat keahlian yang tinggi sehingga mampu memenuhi tuntutan pertumbuhan perusahaan yang cepat.

$\mathrm{H}_{3}$ : Rentabilitas berpengaruh terhadap Pergantian Auditor

\section{Pengaruh Ukuran Kantor Akuntan Publik Terhadap Pergantian Auditor}

Kantor Akuntan Publik yang selanjutnya disingkat KAP adalah badan usaha yang didirikan berdasarkan ketentuan perundang-undangan dan mendapatkan izin usaha berdasarkan Undang-undang Nomor 5 Tahun 2011 tentang Akuntan Publik. Ukuran KAP merupakan ukuran yang digunakan untuk menentukan besar kecilnyasuatu KAP. Ukuran KAP dapat dikatakan besar jika KAP tersebut berafiliasi dengan Big-4, mempunyai cabang dan kliennya perusahaan-perusahaan besar serta mempunyaitenaga profesional di atas 25 orang. Sedangkan ukuran KAP dikatakan kecil jika tidakberafiliasi dengan Big-4tidak mempunyai kurang dari 25 orang (Elder et all 2011).

Perusahaan akan mencari KAP yang berskala besar atau KAP yang berafiliasi dengan Big-4 karena investor dan pengguna laporan keuangan lainnya menganggap dan lebih percaya pada hasil audit yang dikeluarkan oleh KAP besar. $\mathrm{H}_{4}$ : Ukuran Kantor Akuntan Publik berpengaruh terhadap pergantian auditor

\section{Pengaruh Ukuran Perusahaan Terhadap Pergantian Auditor}

Ukuran perusahaan merupakan besar kecilnya perusahaan berdasarkan total aset. Semakin besar total aset perusahaan dapat diindikasikan perusahaan tersebut adalah perusahaan besar. Sebaliknya, semakin kecil total aset perusahaan diindikasikan bahwa perusahaan tersebut adalah perusahaan kecil (Wijaya dan Rasmini 2015).

Pradipta (2014) mengatakan bahwa ketika ukuran perusahaan menjadi besar maka pihak pemilik atau prinsipal akan semakin sulit dan semakin kompleks untuk memonitor tindakan yang dilakukan manajemen. Sesuai dengan teori agensi, manajemen dianggap cenderung untuk memaksimalkan keuntungan pribadi daripada mengutamakan keuntungan prinsipal. Jika perusahaan dikategorikan besar maka prinsipal juga menginginkan auditor yang semakin besar pula. $\mathrm{H}_{5}$ : Ukuran Perusahaan berpengaruh terhadap Pergantian Auditor 
Bagian ini membahas mengenai pengumpulan dan pemilihan data, definisi operasional dan pengukuran variabel, dan teknik analisis data.

\section{Pengumpulan dan Pemilihan Data}

Jenis penelitian ini adalah penelitian asosiatif yang bertujuan untuk menguji pengaruh variable independen terhadap variable dependen. Objek penelitian pada penelitian ini adalah perusahaan manufaktur yang terdaftar di Bursa Efek Indonesia periode 2008-2015.Jenis data yang digunakan dalam penelitian ini adalah data kuantitatif. Sumber data yang digunakan pada penelitian ini adalah sumber data sekunder. Data pada penelitian ini bersumber dari laporan keuangan auditan perusahaan yang tersedia di Pojok BEI Universitas Lambung Mangkurat dan melalui situs resmi BEI di www.idx.co.id.

Populasi dalam penelitian ini adalah perusahaan manufaktur yang terdaftar di BEI dari tahun 2008 sampai tahun 2015. Pemilihan sampel dalam penelitian ini menggunakan metode purposive sampling, yaitu teknik pengambilan sampel secara tidak acak yang informasinya diperoleh dengan mempertimbangkan kriteria tertentu.

Pengumpulan data dalam penelitian ini menggunakan metode dokumentasi yaitu mengumpulkan dan mempelajari dokumen-dokumen dan data yang diperlukan. Data yang dimaksud adalah data sekunder berupa laporan keuangan auditan perusahaan manufaktur yang terdaftar di BEI dengan periode penelitian dari tahun 2008 hingga 2015.

\section{Definisi Operasional dan Pengukuran Variabel}

Variabel independen dalam penelitian ini adalah pergantian auditor, sedangkan variabel dependen adalah financial distress, pertumbuhan perusahaan, rentabiltas, ukuran kantor akuntan publik, dan ukuran perusahaan. Definisi operasional dan pengukuran variabel akan diuraikan sebagai berikut:

\section{Pergantian Auditor}

Pergantian auditor adalah perilaku yang dilakukan oleh perusahaan untuk berpindah auditor baik secara wajib maupun secara sukarela. Peraturan yang mengatur pergantian auditor adalah Peraturan Menteri Keuangan Republik Indonesia Nomor 17/PMK.01/2008 tentang "Jasa Akuntan Publik" yaitu maksimal selama 3 tahun berturut-turut. Dalam penelitian ini, variabel pergantian auditor adalah variabel dummy. Jika perusahaan melakukan pergantian auditor, maka diberikan nilai 1 . Sebaliknya, apabila perusahaan tidak melakukan pergantian auditor, maka diberikan nilai 0 (Wijaya, 2011).

\section{Financial Distress}

Financial distress merupakan suatu kondisi dimana perusahaan mengalami kondisi yang tidak sehat ataupun kesulitan keuangannya sehingga dikhawatirkan akan mengalami kebangkrutan (Wijaya, 2011). Dalam penelitian ini, financial distress diproksikan dengan rasio DER (Debt to Equity Ratio) yang mengacu pada penelitian Putra (2014), Wijaya (2011), dan Pradhana dan Saputra (2015). Adapun cara menghitungnya adalah sebagi berikut:

$$
\text { DER }=\frac{\text { Total Kewajiban }}{\text { Total Ekuitas }} \times 100 \%
$$


Pengaruh

Financial

Distress...

878
Pengukuran variabel financial distress menggunakan variabel dummy. Apabila perusahaan memiliki tingkat rasio DER di atas 80\%, maka diberikan nilai 1 . Sebaliknya, apabila perusahaan tingkat rasio DER di bawah $80 \%$ maka diberikan nilai 0 (Wijayani \& Januarti, 2011).

\section{Pertumbuhan Perusahaan}

Pertumbuhan ini menunjukkan bahwa bisnis yang dijalankan oleh perusahaan tidak mengalami stagnancy (Wijaya, 2011). Pengukuran pertumbuhan perusahaan pada penelitian ini diukur menggunakan proksi pertumbuhan penjualan. Adapun rumus yang digunakan dalam menghitung pertumbuhan penjualan adalah sebagai berikut:

$\Delta S=\frac{S t-(S t-1)}{S t-1}$

Keterangan:

$\Delta \mathrm{S}:$ Rasio pertumbuhan penjualan

St : Penjualan bersih pada periode tahun $t$

St-1 : Penjualan bersih pada periode tahun $\mathrm{t}-1$

\section{Rentabiltas}

Rentabilitas adalah kemampuan perusahaan untuk menghasilkan laba selama periode tertentu Riyanto (2001).Rentabilitas pada penelitian ini diproksikan dengan Return On Asset (ROA), mengacu pada penelitian yang dilakukan oleh Putra (2014).Berikut ini adalah rumus untuk menghitung rasio ROA adalah sebagai berikut:

ROA $=\frac{\text { Laba Bersih }}{\text { Total Aset }} \times 100 \%$

\section{Ukuran Kantor Akuntan Publik}

Ukuran KAP merupakan ukuran yang digunakan untuk menentukan besar kecilnya suatu KAP. Ukuran KAP dapat dikatakan besar jika KAP tersebut berafiliasi dengan Big-4, dan dikatakan kecil jika tidak berafiliasi dengan Big-4. variabel ukuran KAP diukur menggunakan variabel dummy. Jika perusahaan diaudit oleh KAP yang berafilisasi dengan Big-4 maka diberikan nilai 1. Sedangkan jika perusahaan diaudit oleh KAP yang berafilisasi dengan non Big-4 maka diberikan nilai 0 .

\section{Ukuran Perusahaan}

Ukuran perusahaan merupakan besar kecilnya perusahaan berdasarkan total aset. Semakin besar total aset perusahaan menunjukkan bahwa ukuran perusahaan semakin besar. Sebaliknya, semakin kecil total aset perusahaan menunjukkan bahwa ukuran perusahaan kecil (Wijayani \& Januarti, 2011). Variabel ukuran perusahaan pada penelitian ini mengacu pada penelitian yang dilakukan Wijaya dan Rasmini (2015) yaitu dengan logaritma natural atas total aset.

Ukuran Perusahaan $=$ Ln Total Aset

\section{Teknik Analisis Data}

Alat analisis yang digunakan dalam penelitian ini adalah regresi logistik (logisticregression). Alasan penggunaan alat analisis regresi logistik (logistic regression) adalah karena variabel dependen bersifat dikotomi (melakukan perganti- 
an auditor dan tidak melakukan pergantian auditor). Asumsinormal distribution tidak dapat dipenuhi karena variabel bebas merupakan campuran antara variabel kontinyu (metrik) dan kategorial (non-metrik) (Ghozali 2016).

Model regresi yang akan terbentuk dalam penelitian ini berdasarkan analisis regresi logistik adalah:

$Y=\beta_{0}+\beta_{1} X_{1}+\beta_{2} X_{2}+\beta_{3} X_{3}+\beta_{4} X_{4}+\beta_{5} X_{5}+e$

Keterangan:

$\beta_{0} \quad:$ Konstan

$\beta_{1}-\beta_{5}:$ Koefisien regresi

$\mathrm{Y} \quad$ : Pergantian Auditor

$\mathrm{X}_{1} \quad$ : Financial Distress

$\mathrm{X}_{2} \quad$ : Pertumbuhan Perusahaan

$\mathrm{X}_{3} \quad$ : Rentabilitas

$\mathrm{X}_{4}$ : Ukuran KAP

$\mathrm{X}_{5} \quad$ : Ukuran Perusahaan

e : Error

\section{HASIL DAN PEMBAHASAN}

Jumlah perusahaan manufakturyang terdaftar di Bursa Efek Indonesia (BEI) pada tahun 2008 sampai tahun 2015 yang dijadikan sebagai populasi pada penelitian ini adalah sebanyak 171 perusahaan. Berdasarkan kriteria dalam pemilihan sampel dengan menggunakan metode purposive sampling, maka didapat jumlah perusahaan yang dijadikan sampel pada penelitian ini adalah sebanyak 52 perusahaan dan total pengamatan penelitian ini selama 8 tahun sehingga total data yang dijadikan sampel penelitian dalam penelitian ini adalah 416 pengamatan.

\section{Statistik Deskrptif}

Sebelum dilakukan pengujian hipotesis. Sebagai langkah awal akan dilakukan analisis statistik deskriptif.

\begin{tabular}{lrrrrr}
\hline & N & Minimum & Maximum & \multicolumn{1}{c}{ Mean } & \multicolumn{1}{c}{$\begin{array}{c}\text { Std. } \\
\text { Deviation }\end{array}$} \\
\hline Pergantian Auditor & 416 & 0,0000 & 1,0000 & 0,086538 & 0,2814961 \\
Financial Distress & 416 & 0,0798 & 8,3938 & 0,919189 & 0,8064686 \\
Pertumbuhan & 416 & $-0,5392$ & 1,4855 & 0,134634 & 0,2126711 \\
Perusahaan & 416 & 0,0008 & 0,6572 & 0,113054 & 0,0947100 \\
Rentabilitas & 416 & 0,0000 & 1,0000 & 0,557692 & 0,4972585 \\
Ukuran KAP & & 61.987 .805$. & 245.435 .000 .0 & 9.471 .824 .506$. & 26.531 .719 .06 \\
Ukuran & 416 & 413 & 00.000 & 920,56 & $5.684,95$ \\
Perusahaan & & & & \\
Valid N (listwise) & 416 & & & &
\end{tabular}

Tabel 1

Statistik Deskriptif

Sumber: Data diolah kembali, 2016

\section{Menilai Keseluruhan Model (Overall Model Fit)}

Pengujian overall model dilakukan untuk mengetahui apakah model yang dihipotesiskan fit dengan data atau tidak. Pengujian ini dilakukan dengan membandingkan nilai antara -2LL awal dengan nilai -2LL akhir. 


\section{Pengaruh \\ Financial \\ Distress...}

880

Tabel 2

Menilai Keseluruhan

Model

Tabel 3

Koefisien

Determinasi

(Nagelkerke R.

Square)

Tabel 4

Kelayakan

Model Regresi

(Hosmer and

Lemeshow Test)
-2LL awal (BlockNumber $=0)$

244,987

-2LL akhir (BlockNumber $=1)$

227,322

Berdasarkan Tabel 2 diketahui bahwa -2LL awal (step 0) adalah sebesar 244,987 dan setelah dimasukkan 5 variabel independen, nilai -2LL akhir (step 1) turun menjadi 227,322. Penurunan nilai -2LL adalah sebesar 17,655. Penurunan nilai -2LL ini menunjukkan model regresi yang lebih baik atau dengan kata lain model yang dihipotesiskan fit dengan data.

\section{Koefisien Determinasi (Nagelkerke R. Square)}

Koefisien determinasi $\left(\mathrm{R}^{2}\right)$ mengukur seberapa jauh kemampuan model dalam menerangkan variasi variabel dependen.

\begin{tabular}{cccc}
\hline Step & -2 Log likelihood & Cox \& Snell R Square & Nagelkerke R Square \\
\hline 1 & $227,322^{\text {a }}$ & 0,042 & 0,093 \\
\hline
\end{tabular}

Sumber: Data diolah kembali, 2016

Berdasarkan tabel 3 diketahui nilai Negelkerke $R$ Square adalah 0,093. Nilai 0,093 menunjukkan variabilitas variabel terikat (dependen) yang dapat dijelaskan oleh variabel bebas adalah sebesar 9,3\%, sedangkan sisanya sebesar 90,7\% dijelaskan oleh variabel-variabel lain diluar dari model penelitian.

\section{Menguji Kelayakan Model Regresi}

Hosmer and Lemeshow's Goodness of Fit Test menguji hipotesis nol bahwa data empiris cocok atau sesuai dengan model (tidak ada perbedaan antara model dengan data sehingga model dapat dikatakan fit).

\begin{tabular}{cccc}
\hline Step & Chi-square & Df & Sig. \\
\hline 1 & 9,912 & 8 & 0,271 \\
\hline
\end{tabular}

Sumber: Data diolah kembali, 2016

Berdasarkan Tabel 4 dapat diketahui bahwa nilai chi-square adalah sebesar 9,912 dengan tingkat signifikansi sebesar 0,201. Berdasarkan hasil tersebut, nilai Hosmer and Lemeshow's Goodness of Fit Test yang tingkat signifikansinya lebih dari 0,05 berarti bahwa hipotesis nol tidak dapat ditolak dan model mampu memprediksi nilai observasi nya atau dapat dikatakan model dapat diterima karena cocok dengan data observasinya.

\section{Matriks Klasifikasi}

Matriks klasifikasi menunjukkan kekuatan prediksi dari model regresi logistik untuk memprediksi kemungkinan pergantian auditor yang dilakukan oleh perusahaan.

\begin{tabular}{lllccc}
\hline & & & \multicolumn{3}{c}{ Prediksi } \\
\cline { 3 - 5 } & & & \multicolumn{2}{c}{ Pergantian Auditor } & \\
\cline { 3 - 5 } & & & $\begin{array}{c}\text { Tidak } \\
\text { Berganti } \\
\text { Auditor }\end{array}$ & $\begin{array}{c}\text { Berganti } \\
\text { Auditor }\end{array}$ & $\begin{array}{c}\text { Percentage } \\
\text { Correct }\end{array}$ \\
\hline Step 1 & $\begin{array}{l}\text { Pergantian } \\
\text { Auditor }\end{array}$ & $\begin{array}{l}\text { Tidak } \\
\text { Berganti } \\
\text { Auditor } \\
\text { Berganti } \\
\text { Auditor }\end{array}$ & 380 & 0 & 100,0 \\
\hline & $\begin{array}{l}\text { Persentase } \\
\text { Total }\end{array}$ & 34 & 2 & 5,6 \\
\hline
\end{tabular}

Sumber: Data diolah kembali, 2016 
Berdasarkan hasil pengujian pada Tabel 5, menunjukkan bahwa kekuatan prediksi dari model regresi untuk memprediksi kemungkinan perusahaan melakukan pergantian auditor adalah sebesar 5,6\%. Kekuatan prediksi model perusahaan yang tidak melakukan pergantian KAP adalah sebesar 100\%. Dapat disimpulkan bahwa kekuatan prediksi dari model regresi sebesar 91,8\%.

\section{Estimasi Parameter dan Interpretasi}

Estimasi parameter dari model dapat dilihat pada output Variable in the Equation.Pengujian terhadap hipotesis dilakukan dengan menggunakan $\alpha=5 \%$. Jika nilai probabilitas (sig.) $<\alpha=5 \%$ maka hipotesis nol ditolak. Sebaliknya, jika nilai probabilitas (sig.) $>\alpha=5 \%$ maka hipotesis nol tidak dapat ditolak.

\begin{tabular}{lllllllll}
\hline & & B & S.E. & Wald & Df & \multicolumn{1}{c}{ Sig. } & Exp(B) & Kesimpulan \\
\hline \multirow{2}{*}{ Step 1a } & X1 & 0,427 & 0,369 & 1,339 & 1 & 0,247 & 1,532 & Ditolak \\
& X2 & 0,952 & 0,742 & 1,647 & 1 & 0,199 & 2,590 & Ditolak \\
& X3 & 4,233 & 1,814 & 5,446 & 1 & 0,020 & 68,943 & Diterima \\
& X4 & $-1,043$ & 0,421 & 6,147 & 1 & 0,013 & 0,352 & Diterima \\
& X5 & 0,000 & 0,001 & 0,085 & 1 & 0,771 & 1,000 & Ditolak \\
& Constant & $-2,769$ & 0,355 & 60,904 & 1 & 0,000 & 0,063 & \\
\hline
\end{tabular}

Tabel 6

Estimasi Parameter dan Interpretasi (Variable in the Equation)

\section{Pengaruh Finansial Distress Terhadap Pergantian Auditor}

Hasil pengujian hipotesis menunjukkan bahwa financial distress memiliki nilai koefisien regresi positif sebesar 0,427 dengan tingkat signifikansi sebesar 0,247. Berdasarkan hasil tersebut, penelitian ini menolak $\mathrm{H}_{1}$ dan menerima $\mathrm{H}_{0}$ karena tingkat signifikansi melebihi 0,05 sehingga dapat disimpulkan financial distress tidak berpengaruh terhadap pergantian auditor. Tidak berpengaruhya financial distress terhadap pergantian auditor diduga bahwa pergantian auditor yang dilakukan oleh perusahaan akan mengakibatkan peningkatan biaya audit. Selain itu, suatu usaha untuk menjaga kepercayaan dan menarik minat para investor untuk berinvestasi pada suatu usaha adalah dengan menggunakan auditornya yang memiliki kemampuan untuk menghasilkan kualitas audit yang lebih tinggi dan lebih independen (Aprilia 2013).

\section{Pengaruh Pertumbuha Perusahaan Terhadap Pergantian Auditor}

Hasil pengujian hipotesis yang keduamenunjukkan bahwa variabel pertumbuhan perusahaan memiliki nilai koefisien regresi positif sebesar 0,952 dengan tingkat signifikansi sebesar 0,199. Berdasarkan hasil tersebut, penelitian ini menolak $\mathrm{H}_{2}$ dan menerima $\mathrm{H}_{0}$ karena tingkat signifikansi melebihi 0,05 sehingga dapat disimpulkan pertumbuhan perusahaan tidak berpengaruh terhadap pergantian auditor. Tidak berpengaruhnya pertumbuhan perusahaan terhadap pergantian auditor diduga karena perusahaan yang mengalami pertumbuhan cenderung akan mempertahankan auditor yang telah ada karena auditor tersebut telah memahami kondisi perusahaan dengan baik dan mempertahankan reputasinya jika perusahaan tetap menggunakan jasa dari auditor yang lama. Selain itu, jika perusahaan melakukan pergantian auditor dapat menyebabkan reputasi perusahaan dan kepercayaan di mata para shareholders-nya menurun. Karena itu pihak manajemen memilih untuk tetap mempertahankan penggunaan jasa auditor lama untuk mempertahankan reputasi perusahaan dan kepercayaan di mata para shareholders-nya. 
Pengaruh

Financial

Distress...

882

\section{Pengaruh Rentabilitas Terhadap Pergantian Auditor}

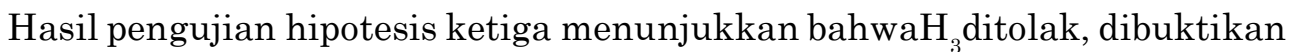
dengan variabel rentabilitas memiliki nilai koefisien regresi positif sebesar 3,910 dengan tingkat signifikansi sebesar 0,037. Berdasarkan hasil tersebut, penelitian ini menerima $\mathrm{H}_{1}$ dan menolak $\mathrm{H}_{0}$ karena tingkat signifikansi kurang dari 0,05 sehingga dapat disimpulkan bahwa rentabilitas berpengaruh terhadap pergantian auditor.Wijaya (2011) mengatakan bahwa perusahaan yang memperoleh peningkatan profitabilitas maka perusahaan mengalami pertumbuhan pada perusahaannya, dengan demikian perusahaan yang sedang mengalami pertumbuhan akan cenderung untuk melakukan auditor switching. Hal ini dikarenakan perusahaan memerlukan auditor yang berkualitas dan mampu memenuhi tuntutan pertumbuhan perusahaan yang cepat. Selain itu, perusahaan yang mengalami peningkatan rentabilitas cenderung mengganti auditornya dengan auditor yang dipandang lebih punya nama sehingga dapat meningkatkan reputasi perusahaan di kalangan investor.

\section{Pengaruh Ukuran KAP Terhadap Pergantian Auditor}

Hasil pengujian hipotesis keempat menunjukkan bahwa $\mathrm{H}_{4}$ diterima, dibuktikan dengan variabel ukuran KAP memiliki nilai koefisien regresi negatif sebesar -1,043 dengan tingkat signifikansi sebesar 0,013. Berdasarkan hasil tersebut, penelitian ini menerima $\mathrm{H}_{1}$ dan menerima $\mathrm{H}_{0}$ karena tingkat signifikansi kurang dari 0,05 sehingga dapat disimpulkan bahwa ukuran KAP berpengaruh terhadap pergantian auditor.Perusahaan akan mencari KAP besar atau yang berafiliasi dengan Big-4untuk mengaudit laporan keuanggannya karena investor dan pengguna laporan keuangan lain lebih percaya pada hasil audit yang dikeluarkan oleh KAP besar atau yang berafiliasi dengan Big-4. Pada penelitian ini, perusahaan sendiri cenderung untuk memilih KAP besar atau yangberafiliasi dengan Big-4 yang memiliki kredibilitas dan tingkat keahlian yang tinggi serta memiliki fugsifungsi kontrol manajemen yang baik dalam melakukan audit mengingat sampel perusahaan penelitian ini adalah perusahaan-perusahaan yang telah go public. Hal ini dilakukan perusahaan untuk mempertahankan reputasi perusahaan dimata shareholdernya dan untuk mempertahankan kepercayaan publik. Selain itu, KAP yang lebih besar juga dianggap lebih independen daripada rekan-rekan mereka yang lebih kecil dalam menahan tekanan manajemen pada saat terjadi perselisihan ketika mereka biasanya memiliki lebih banyak klien dan mampu untuk menyerahkan sebagian dari klien mereka yang lebih sulit (Divianto 2011).

\section{Pengaruh Ukuran Perusahaan Terhadap Pergantian Auditor}

Hasil pengujian hipotesis kelima menunjukkan bahwa $\mathrm{H}_{5}$ ditolak, dibuktikan dengan variabel ukuran perusahaan memiliki nilai koefisien regresi negatif sebesar 0,000 dengan tingkat signifikansi sebesar 1,000. Berdasarkan hasil tersebut, penelitian ini menolak $\mathrm{H}_{1}$ dan menerima $\mathrm{H}_{0}$ karena tingkat signifikansi melebihi 0,05 sehingga dapat disimpulkan bahwa ukuran perusahaan tidak berpengaruh terhadap pergantian auditor. Tidak berpengaruhnya variabel ukuran perusahaan pada penelitian ini menunjukan bahwa diduga setiap perusahaan yang mengalami peningkatan atau penurunan dalam skala ukuran perusahaan yang dilihat dari total aset perusahaan tidak selalu diikuti dengan melakukan pergantian auditor. Alasannya karena pergantian auditor membutuhkan penyesuaian yang cukup lama baik antara klien dan auditornya, karena dalam hal ini auditor harus memahami betul unit bisnis perusahaan klien dan harus mengetahui keadaan dari perusahaan klien yang sebenarnya yang membutuhkan biaya yang tidak sedikit dan waktu yang cukup lama. 
Berdasarkan hasil pengujian dan pembahasan yang dijelaskan pada bagian sebelumnya, maka dapat disimpulkan bahwa variabelfinancial distress, pertumbuhan perusahaan dan variabel ukuran peerusahaantidak berpengaruh terhadap pergantian auditor.Sedangkan variabel rentabilitas dn ukuran KAP berpengaruh terhadap pergantian auditor.

Penelitian selanjutnya diharapkan bisa memperluas sampel penelitian tidak hanya sektor manufaktur saja, bisa mempertimbangkan sektor-sektor lainnya yang terdaftar di BEI.Penelitian selanjutnya dapat menggunakan variabel-variabel lain sebagai variabel independen seperti kualitas audit, fee audit, kepemilikian publik, pergantian manajemen, reputasi auditor, audit delay, atau dapat menambah variabel lain diluar model penelitian ini karena variabilitas variabel dependen yang dapat dijelaskan oleh variabel independen dalam penelitian ini masih rendah.

\section{Implikasi Hasil Penelitian}

Hasil penelitian ini diharapkan dapat memberikan kontribusi pada pengembangan ilmu pengetahuan akuntansi yang khususnya dibidang auditing yang membahas mengenai pergantian auditor. Selain itu, hasil penelitian ini dapat digunakan sebagai salah satu acuan bagi peneliti selanjutnya yang tertarik ingin melakukan penelitian dengan topik yang serupa dengan penelitian ini. Bagi perusahaan, penelitian ini diharapkan dapat memberikan kontribusi praktis tentang informasi faktor-faktor apa saja yang yang dapat berpengaruh terhadap keputusan perusahaan dalam melakukan pergantian auditor. Hasil peneliian ini menunjukkan bahwa variabel rentabilitas dan ukuran KAP berpengaruh terhadap pergantian auditor.

\section{Keterbatasan Penelitian}

Penelitian ini memiliki beberapa keterbatasan yang mungkin dapat melemahkan hasil penelitian. Keterbatasan dalam penelitian ini adalah sebagai berikut:

1. Data perusahaan yang mengalami financial distress lebih sedikit dibandingkan dengan data perusahaan yang tidak mengalami financial distress, sehingga data yang dimasukkan pada saat pengujian menjadi tidak seimbang. Ketidakseimbangan data diduga menyebabkan variabel ini tidak berpengaruhnya variabel financial distress terhadap pergantian auditor.

2. Terdapat ketidak seimbangan antara data perusahaan yang mengalami pertumbuhan perusahaan negatifatau mengalami penurunan dengan perusahaan yang tidak mengalami kenaikan pada pertumbuhan perusahaannya sehingga ketika dilakukan pengujian terhadap variabel pertumbuhan perusahaan, variabel ini tidak mempunyai pengaruh terhadap pergantian auditor.

3. Pada penelitian ini, hampir seluruh perusahaan memiliki ukuran perusahaan yang besar. Hanya terdapat 9 perusahaan dari total 416 perusahaan sampel yang memiliki ukuran perusahaan yang kecil. Hal ini diduga yang menyebabkan variabel ukuran perusahaan tidak memilik pengaruh terhadap pergantian auditor.

\section{DAFTAR PUSTAKA}

Aprilia, E. 2013. "Analisis Faktor-Faktor Yang Mempengaruhi Auditor Switching”. Accounting Analysis Journal. Vol. 2. No.2. hlm. 199-207. 
Pengaruh

Financial

Distress...

884
Arsih, L., and I. Anisykurlillah. 2015. "Pengaruh Opini Going Concern, Ukuran KAP dan Profitabilitas Terhadap Auditor Switching". Accounting Analysis Journal. Vol. 4. No.3. hlm. 1-10

Astuti, N. L. and I.W. Ramantha. 2014. "Pengaruh Audit Fee, Opini Going Concern, Financial Distress dan Ukuran Perusahaan". E-Jurnal Akuntansi Universitas Udayana. Vol. 7 No. 3.

Brigham, E.F. and P.R. Daves. 2003. "Intermediate Financial Management with Thomson One”. Cengage South-Western. United States of America

Divianto. 2011. "Faktor-Faktor Yang Mempengaruhi Perusahaan Dalam Melakukan Auditor Switch". Jurnal Ekonomi dan Informasi Akuntansi (Jenius). Vol. 2.

Elder, R.J., M.S. Beasly, A.A. Arens, and A.A. Jusuf. 2011. "Jasa Audit dan Assurance: Pendekatan Terpadu (Adaptasi Indonesia)”. Salemba Empat. Jakarta.

Ghozali, I. 2016. “Aplikasi Analisis Multivariate dengan IMB SPSS 23”. Badan Penerbit Universitas Diponegoro. Semarang.

Ikhsan, A., S. Lesmana, and A. Hayat. 2015. "Teori Akuntansi”. Citapustaka Media. Bandung.

Kasmir. 2011. "Analisa Laporan Keuangan”. Raja Grafindo. Jakarta.

Menteri Keuangan. 2002. "Keputusan Menteri Keuangan Republik Indonesia Nomor 423/KMK..06/2002 Tentang Jasa Akuntan Publik".

Menteri Keuangan. 2002. "Keputusan Menteri Keuangan Republik Indonesia Nomor 359/KMK..06/2003 Tentang Jasa Akuntan Publik".

Menteri Keuangan. 2008. "Peraturan Menteri Keuangan Republik Indonesia Nomor 17/PMK.01/2008 Tentang Jasa Akuntan Publik".

Munawir. 2014. "Analisa Laporan Keuangan”. Liberty. Yogyakarta.

Pradhana, M.A. and I.D. Suputr. 2015. "Pengaruh audit Fee, Opini Going Concern, Financial Distress, Ukuran Perusahaan dan Pergantian Manajemen pada Pergantian Auditor". E-Jurnal Akuntansi Universitas Udayana. Vol. 11. No. 3.

Pradipta, R.P. 2014. "Faktor-faktor yang Mempengaruhi Perusahaan Manufaktur Terdaftar Di BEI Melakukan Pergantian Auditor Secara Voluntary". Diponegoro Journal Of Accounting. Vol. 3.

Pratini, I.A. and I.P. Astika. 2013. "Fenomena Pergantian Audtor Di Indonesia". Ejurnal Akuntansi Universitas Udayana. Vol. 5. No. 2.

Putra, I.W. 2014. "Pengaruh Financial Distress, Rentabilitas, Pertumbuhan Perusahaan dan Opini Audit pada Pergantian Auditor". E-Jurnal Akuntansi Universitas Udayana. Vol. 8. No. 2.

Riyanto, B. 2001. "Dasar-dasar Pembelanjaan Perusahaan”. BPFE. Yogyakarta.

Wijaya, E. and N.K. Rasmini. 2015. "Pengaruh Audit Fee, Opini Going Concern, Financial Distress, Ukuran Perusahaan, Ukuran KAP, pada Pergantian $\mathrm{Au}^{-}$ ditor". E-Jurnal Akuntansi Universitas Udayana. Vol. 11 No. 3.

Wijaya, R.M.A.P. 2011. "Faktor-Faktor Yang Mempengaruhi Pergantian KAP oleh Auditor". Jurnal Ilmiah Mahasiswa FEB. Vol. 1. No. 1

Wijayani, E.D. and I. Januarti. 2011. "Analisis Faktor-faktor yang Mempengaruhi Perusahaan Di Indonesia Melakukan Auditor Switching". Simponsium Nasional Akuntansi XIV. Juli. Aceh 